$5 \quad$ Liu $^{\text {d* }}$ 3 Liu ${ }^{d}$

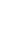
17 8

\title{
Screening of Isochrysis strains and utilization of a two-stage outdoor cultivation strategy for algal biomass and lipid production
}

Zheng Sun ${ }^{\text {a,b,c }}$, Hehong Wei ${ }^{\text {d }}$, Zhi-gang Zhou ${ }^{\text {a,b,c }}$, Muthupandian Ashokkumar ${ }^{\text {e }}$, Jin

${ }^{a}$ International Research Center for Marine Biosciences, Ministry of Science and Technology, Shanghai Ocean University, Shanghai, 201306 China

${ }^{b}$ Key Laboratory of Exploration and Utilization of Aquatic Genetic Resources, Ministry of Education, Shanghai Ocean University, Shanghai, 201306 China

${ }^{c}$ National Demonstration Center for Experimental Fisheries Science Education, Shanghai Ocean University, Shanghai, 201306 China

${ }^{d}$ Institute for Food and Bioresource Engineering, Department of Energy and Resources Engineering and BIC-ESAT, College of Engineering, Peking University, Beijing 100871, China

${ }^{e}$ School of Chemistry, University of Melbourne, VIC 3010, Australia

9 * To whom corresponding should be addressed:

Tel.: 86-10-62766391; E-mail: gjinliu@pku.edu.cn 
23

\section{Abstract}

Isochrysis is genus of marine algae without cell wall and capable of accumulating lipids. In this study, the lipid production potential of Isochrysis was assessed by comparing fifteen Isochrysis strains with respect to their growth rate, lipid production and fatty acid profiles. Three best strains were selected (lipid productivity: 103.0 121.7 $m g \mathrm{~L}^{-1}$ day $^{-1}$ ) and their lipid-producing capacities were further examined under different controlled parameters, e.g., growth phase, medium nutrient and light intensity in laboratory cultures. Furthermore, the three Isochrysis strains were monitored in outdoor panel photobioreactors with various initial cell densities and optical paths, and the strain CS177 demonstrated the superior potential for outdoor cultivation. A two-stage semi-continuous strategy for CS177 was subsequently developed, where high productivities of biomass $\left(1.1 \mathrm{~g} \mathrm{~L}^{-1}\right.$ day $\left.^{-1}\right)$ and lipid $\left(0.35 \mathrm{~g} \mathrm{~L}^{-1}\right.$ day $\left.^{-1}\right)$ were achieved. This is a comprehensive study to evaluate the lipid-producing capability of Isochrysis strains under both indoor and outdoor conditions. Results of the present work lay a solid foundation for the physiological and biochemical responses of Isochrysis to various conditions, shedding light on the future utilization of this cell wall-lacking marine alga for biofuel production.

Key Words: Isochrysis, Screening, Biofuel feedstock, Two-stage outdoor cultivation 
60
- Fifteen Isochrysis strains were screened for lipid production

- Key biological and engineering parameters were optimized for indoor /outdoor cultures

- A two-stage semi-continuous strategy was developed

- High-quality oil production and robustness in outdoor cultivation were demonstrated 


\section{Introduction}

The ever-increasing consumption of energy worldwide and the concerns over global warming call for alternatives to fossil fuels. The exploitation of the available sources for biodiesel started from the food crops to woody crops, agricultural residues or waste, and now has come to microalgae Compared with higher plants, microalgae grow much faster and are able to produce a great variety of lipids [1]. Furthermore, microalgae can be adapted to grow in a broad range of environmental conditions, so that they do not compete with food for arable lands [2]. As such, microalgae have been hailed as the solution to the global energy crisis, though many challenges remain to be addressed.

To move the algal biodiesel from promise to reality, the selection of appropriate algal strains is the first and most fundamental step. Through literature search, the green algae (Chlorophyta) and diatoms (Bacillariophyta) have been the most commonly-studied ones regarding the lipid-producing capability [1, 3-5]. The present work is focused on Isochrysis, a genus of marine flagellated algae. There are several reasons that Isochrysis could be a promising biodiesel feedstock: 1) it belongs to marine algae and is suitable for growing with seawater, thus avoiding the competition for freshwater; 2) it has a fast growth rate for biomass production [6]; 3) Isochrysis has no cell walls, so that the oil extraction from Isochrysis is much easier than other algae, which can vastly enhance the economics of down-stream processing for biodiesel production; 4) it has high concentrations of docosahexaencic acid (DHA, 22: 6n-3), a valuable omega-3 polyunsaturated fatty acid with significant nutritional and 
healthy benefits $[7,8]$. . Therefore, it is highly possible to develop the integrated production of oil and value-added products from Isochrysis, which is crucial for the commercialization of microalgae-based biodiesel; 5) from a biorefinery point of view, the residual biomass after oil extraction can be used as feeds for aquaculture applications [9].

The main objective of this study is to select a high-performance Isochrysis strain and optimize several key biological and engineering parameters for the improved lipid production. Fifteen Isochrysis strains were used for comparative analysis with respect to their growth, lipid content, lipid productivity and fatty acid profile. The best strain CS177, which showed the highest lipid productivity and most suitable fatty acid composition, was investigated by subjecting to several nutritional and environmental factors. Its biomass and oil production potential was further evaluated in outdoor panel photobioreactors (PBRs) by manipulating the initial cell density and length of optical path. Furthermore, a two-stage semi-continuous cultivation strategy, which is suitable for outdoor algal growth under sunlight, was developed to promote the biomass and lipid production. The biomass and lipid productivities achieved are higher or comparable to previous reports of algal strains, shedding light on the further exploration of this cell wall-lacking marine alga for lipid production in pilot-scale PBRs or open ponds.

\section{Materials and methods}

\section{Isochrysis strains and maintenance}


108

Fifteen Isochrysis strains were used in the present study, including CCMP 355, 463, 715, 1244, 1324, 1611 from Provosoli-Guillard National Center for Culture of Marine Phytoplankton, UTEX 987, 1292, 2307 from the Culture Collection of Algae at the University of Texas, CCAP 927/1, 927/12, 927/14 from Culture Collection of Algae and Protozoa, CS 177, 254 from Australian National Algae Culture Collection and LABI 1100 maintained at Peking University, China. All strains were maintained in 250-mL Erlenmeyer flasks containing $100 \mathrm{~mL} \mathrm{F/2} \mathrm{medium} \mathrm{and} 25 \mathrm{~g} \mathrm{~L}^{-1}$ sea salt (Central Aquatics, Franklin, WI, USA). Cultures were kept at $22^{\circ} \mathrm{C}$ with continuous illumination of a low light $\left(20 \mu \mathrm{mol} \mathrm{m} \mathrm{m}^{-2} \mathrm{~s}^{-1}\right.$. Cultures were shaken by hand once a day.

\section{Strain screening in $100-\mathrm{mL}$ bubble column photobioreactors}

Algal cultures in flasks were inoculated into column photobioreactors (PBRs, internal diameter $=3.0 \mathrm{~cm})$ containing $100 \mathrm{~mL}$ modified $\mathrm{F} / 2$ medium $\left(200 \mathrm{mg} \mathrm{L}^{-1} \mathrm{~N}\right.$ and 9 mg $\mathrm{L}^{-1} \mathrm{P}$ ) and grew at $22^{\circ} \mathrm{C}$ aerated with $1.5 \% \mathrm{CO}_{2}$ enriched air (compressed air and $\mathrm{CO}_{2}$ are mixed at a ratio of 100:1.5) and illuminated with continuous light of 60 $\mu \mathrm{mol} \mathrm{m} \mathrm{m}^{-2} \mathrm{~s}^{-1}$. The cultures in late exponential growth phase were inoculated into new column PBRs with a starting cell density of $0.1 \mathrm{~g} \mathrm{~L}^{-1}$, cultured to late exponential growth phase, and harvested for the analysis of growth and lipids.

CCMP1244, CCMP1324 and CS177 exhibited the comparably high growth and lipid productivity and were therefore selected for further study. Their growth and lipid production were investigated in response to different growth phases, nitrate and phosphate concentrations, and light intensities. Unless otherwise stated, the basal 
130

131

132

133

134

135

136

137

138

139

140

141

142

culture conditions were the same as those used for strain screening (i.e., $200 \mathrm{mg} \mathrm{L}^{-1} \mathrm{~N}$, $9 \mathrm{mg} \mathrm{L}^{-1} \mathrm{P}$, light intensity of $60 \mu \mathrm{mol} \mathrm{m}^{-2} \mathrm{~s}^{-1}$, salinity of $25 \mathrm{~g} \mathrm{~L}^{-1}$ ).

\section{Outdoor cultures in flat-plate PBRs}

Cultures of the three strains were conducted in the outdoor panel PBRs arranged in a South-North orientation in summer in Shanghai, China (latitude $31^{\circ} 140^{\prime} \mathrm{N}$, longitude $121^{\circ} 290^{\prime}$ E). The PBRs are $140-\mathrm{cm}$ high and $120-\mathrm{cm}$ long. Compressed air was bubbled through a perforated plastic tube running at the bottom of the reactors to mix algal suspension. A stainless iron tube-based thermo-exchanger was placed in each PBR to prevent the culture temperature from exceeding $30^{\circ} \mathrm{C}$. During the night, the cooling system was turned off to allow the cultures to follow the ambient temperature.

Seed cultures were maintained in 20-L indoor panel PBRs with continuous illumination of $100 \mu \mathrm{mol} \mathrm{m} \mathrm{m}^{-2} \mathrm{~s}^{-1}$ to late exponential growth phase and inoculated into outdoor panel PBRs at 6:00 PM (consider this day as day 0). Cell samples were collected every day at 6:00 PM for analyses.

CS177 showed the best growth performance and was further investigated. To optimize the outdoor growth and lipid production, PBRs with various internal widths being 1.8, 3.5, and $7.0 \mathrm{~cm}$ (corresponding to the optical path lengths of the reactor) were employed. The CS177 seeds were inoculated either at the same initial volumetric cell density $\left(0.6 \mathrm{~g} \mathrm{~L}^{-1}\right)$ or at the same initial areal cell density $\left(21 \mathrm{~g} \mathrm{~m}^{-2}\right)$.

Semi-continuous culture experiments were also performed. Cells were first inoculated in a 7.0-cm panel PBR with a low cell density of $0.3 \mathrm{~g} \mathrm{~L}^{-1}$ and allowed to grow for 2 days to reach a high cell density of $\sim 1.2 \mathrm{~g} \mathrm{~L}^{-1}$, which were then transferred to a 1.8 -cm 
152

153

154

155

156

157

158

159

160

161

162

PBR for rapid biomass and lipid production. Semi-continuous cultivation was deployed in the thin PBR, with a harvest of 3/4 cultures per 3 days.

\section{Growth measurements}

The optical density (OD) of culture was measured at $750 \mathrm{~nm}$ with a $1.5 \mathrm{~cm}$ light path cuvette in a HACH DR 2700 spectrophotometer. Culture suspension (5-10 mL) was filtered through a pre-dried Whatman GF/C filter paper (1.2 $\mu \mathrm{m}$ pore size) and washed twice with $10 \mathrm{~mL} 0.5 \mathrm{M} \mathrm{NH}_{4} \mathrm{HCO}_{3}$. Cells on the filter paper discs were dried at $100^{\circ} \mathrm{C}$ in an oven until constant weight and were subsequently cooled to room temperature in a desiccator before weighing. Samples were ashed at $500^{\circ} \mathrm{C}$ for 2 hours in a muffle furnace to obtain ash-free dry weight (AFDW). Biomass productivity was calculated on an AFDW basis.

\section{Nitrate and phosphate measurements}

Algal suspensions were centrifuged at 3,800 g for 5 min and the supernatants were collected to measure the residual nitrate-N and phosphate-P by using a Quickchem 8500 (Lachat, Loveland, Colorado, USA) according to the instructions provided by the manufacturer.

\section{Lipid and fatty acid analyses}

Cells were centrifuged at 3,800 g for 5 min. The pellet was lyophilized for fatty acid analysis. Lipids were extracted from lyophilized algal samples with a solvent mixture of chloroform, methanol and water (2:1:0.75, by volume) according to a modified Folch procedure [10]. The extracts were dried under nitrogen gas, and then weighed. Dry lipid extracts were re-suspended in chloroform for immediate use or stored at 
$-20^{\circ} \mathrm{C}$ under nitrogen for later use.

Fatty acid methyl esters (FAMEs) were prepared by direct transmethylation of lipids with sulphuric acid in methanol [10]. The FAMES were separated by GC-MS using the Agilent 7890 capillary gas chromatograph equipped with a 5975 C mass spectrometry detector and a HP-88 capillary column (60 m x $0.25 \mathrm{~mm}$ ) (Agilent Technologies). The temperature program consisted of an initial hold at $100^{\circ} \mathrm{C}$ for 5 min, ramping at $3.5^{\circ} \mathrm{C} \min ^{-1}$ to $240^{\circ} \mathrm{C}$, and a final hold at $240^{\circ} \mathrm{C}$ for $5 \mathrm{~min}$. The injector was kept as $250^{\circ} \mathrm{C}$ with an injection volume of $2 \mu \mathrm{L}$ in a splitless mode. The flow rate of the carrier gas (Helium) was $1.5 \mathrm{ml} \mathrm{min}^{-1}$, and the ionization energy was 70 eV (EI, full scan mode). DHA in samples was quantified by using DHA standard (Sigma, St. Louis, MO, USA).

The biodiesel properties including kinematic viscosity, specific gravity, cloud point, cetane number, iodine value, and higher heating value were predicated based on the FAME composition using the equations described by Ramos et al. [11] and Hoekman et al. [12].

\section{Statistical analyses}

All data were obtained by using at least two biological samples to ensure the reproducibility of the results. Experimental results were expressed as mean value \pm SD. Statistical analysis was performed using the SPSS statistical package (SPSS Inc., Chicago, IL, USA). Paired-samples T-test was used for two group means and one-way ANOVA Tukey's HSD test was used for over two group means. The statistical significance was achieved when $\mathrm{p}<0.05$. 
197 Results and discussion

198 Screening of Isochrysis strains for lipid production

199 Fifteen Isochrysis strains were screened with respect to cell density, lipid content and 200 lipid productivity. As indicated by Fig. 1A, the cell density ranged from 0.65 to $3.99 \mathrm{~g}$ 201 $\mathrm{L}^{-1}$, suggesting that the growth potential of Isochrysis is strain-dependent. The three 202 fastest growing strains were CCMP1324, CCMP1244 and CS177, whose cell 203 densities within a 10-day cultivation reached 3.51, 3.69 and $3.99 \mathrm{~g} \mathrm{~L}^{-1}$, respectively. 204 As for the biomass productivities, the three were all above $0.3 \mathrm{~g} \mathrm{~L}^{-1}$ day $^{-1}$. This is 205 superior to a vast number of microalgae, as the biomass productivity of many algal 206 strains lie between 0.1 and $0.3 \mathrm{~g} \mathrm{~L}^{-1}$ day $^{-1}$ [13]. The lipid content of Isochrysis varied 207 across strains in the range of $19.8-30.5 \%$ of dry weight, and CS177 accumulated the 208 highest level of lipids (30.5\%, Fig. 1B). High lipid productivity is another desirable 209 characteristic of an algal strain for biodiesel production. Green microalgae usually 210 produce large amounts of lipids within a relatively short period, whose average lipid 211 productivity was about $70 \mathrm{mg} \mathrm{L}^{-1}$ day $^{-1}$, much better than that of other algae ( 30 mg $212 \mathrm{~L}^{-1}$ day $^{-1}$ ) [13]. In the present study, the lipid productivity of several Isochrysis strains 213 has exceeded this value, with the highest (CS177) being $122 \mathrm{mg} \mathrm{L}^{-1}$ day $^{-1}$ (Fig. 1C).

214 The characteristics of fatty acids of Isochrysis strains were also examined, because 215 they determine, to a great extent, the key properties of biodiesel. As indicated by 216 Table 1, the fatty acid composition among the fifteen strains was quite similar, mainly 217 consisting of myristic acid (C14:0), palmitic acid (C16:0), oleic acid (C18:1), 
stearidonic acid (C18:4) and docosahexaenoic acid (C22:6). On the other hand, the level of individual fatty acids varied greatly, for example, C14:0 ranging from 9.3 to 30.8\%, C18:1 from 21.5 to $34.0 \%$, and C22:6 from 5.3 to $17.7 \%$ of total fatty acids. Compared with saturated fatty esters, the unsaturated ones have sound low-temperature properties to prevent the solidification of oil; on the other hand, their oxidative stability is much poorer [14]. To reach a compromise between oxidative stability and cold-flow properties, a high proportion of oleic acid (C18: 1) ester is preferred [15]. In the present study, all Isochrysis strains contained a high level of C18:1 ( 20-30\%), indicating they are the suitable feedstock for biodiesel.

[Table 1 near here]

We further evaluated the biodiesel properties of Isochrysis-derived oils, including kinematic viscosity, specific gravity, cloud point, cetane number, iodine value and higher heating value. As shown in Table 2, the oils from most Isochrysis strains meet the specification established by US (ASTM D6751) and Europe (EN 14214) standards. Based on these results, three strains demonstrating the highest potential for oil production, namely CCMP1244, CCMP1324 and CS177 were selected for further investigation.

[Table 2 near here]

\section{Lipid and fatty acid profiles of Isochrysis strains as affected by growth phases}

During algal cultivation, the accumulation of metabolites may vary greatly depending upon the growth phases of the culture. In the present study, the lipid contents and fatty acid profiles of the three Isochrysis strains were analyzed under different growth 
phases, i.e. early exponential (EE), late exponential (LE), and late stationary (LS). As

241 shown in Fig. 2A, all three strains showed just a slight increase of total lipids when

242 cells entered stationary growth phase, and this observation is consistent with previous

243 reports on Isochrysis [6]. The total fatty acid (TFA) profile, on the other hand, showed

244 distinct patterns among the three strains (Fig. 2B-D). In the EE stage, CS177

245 exhibited the highest relative abundance of C14:0 (37.2\%) but the lowest C22:6

246 (5.1\%). When cultured to LE and LS stages, all three strains showed a considerable

247 decrease in C14:0 with a concomitant increase in C18:1.

\section{Growth and lipid production as affected by medium nutrients}

249 Nitrogen $(\mathrm{N})$ is the second main component of algal biomass after carbon. As an

250 essential macronutrient for algae, the concentration of $\mathrm{N}$ greatly influences the

251 intracellular lipid accumulation. N limitation /starvation is usually associated with the

252 enhanced synthesis of lipids, in particular neutral lipids [16, 17]. It could be because

253 that when the nitrogen gets limited or exhausted, carbon uptake continues and will be

254 consequently accumulated within algal cells as lipids. On the other hand, a low

255 concentration of $\mathrm{N}$ limits the algal growth. Therefore, the optimization of $\mathrm{N}$ contents

256 is of great importance to maximize the lipid accumulation whilst maintaining a proper

257 algal growth. In the present study, four concentrations of nitrate-N (25 - $200 \mathrm{mg} \mathrm{L}^{-1}$ )

258 were tested. As shown in Fig. 3A, when the initial N concentration ranged from 25 to

$259100 \mathrm{mg} \mathrm{L}^{-1}$, all three strains could efficiently utilize nitrate-N with a closely complete

260 consumption at the end of culture period (Fig. 3A). The final cell density was

261 positively dependent on the initial $\mathrm{N}$ concentration and reached the maximum with an 
262

263

initial $\mathrm{N}$ concentration of $100 \mathrm{mg} \mathrm{L}^{-1}$ (Fig. 3B). Further increase in $\mathrm{N}$ concentration to $200 \mathrm{mg} \mathrm{L} \mathrm{L}^{-1}$ gave no beneficial effect on cell density (Fig. 3B) and there were substantial amounts of unconsumed $\mathrm{N}$ (Fig. 3A), indicating that other factors than $\mathrm{N}$ became limiting in the batch cultures. The lipid content of Isochrysis strains showed a slight difference in response to the initial $\mathrm{N}$ concentration and was promoted slightly by lower $\mathrm{N}$ concentrations (Fig. 3C), differing a lot from other algae such as Chlorella and Nannochloropsis strains in which the lipid content was influenced considerably by $\mathrm{N}$ limitation /starvation $[18,19]$. This may be explained by the fact that Isochrysis strains utilize the recycled membrane lipids rather than the de novo synthesized fatty acyls for neutral lipid synthesis upon N stress [20]. Similarly, the lipid productivity of Isochrysis was in a $\mathrm{N}$ concentration-dependent manner, which reached the maximum at $100-200 \mathrm{mg} \mathrm{L}^{-1} \mathrm{~N}$ (Fig. 3D). Given the huge diversity of microalgae, nitrogen limitation may not always be linked to lipid accumulation. For example, the diatoms Achnanthes brevipes and Tetraselmis spp. accumulate carbohydrates rather than lipids upon nitrogen starvation [21, 22], and their enhanced lipid synthesis was found to be associated with silicate limitation [23].

Phosphorus (P) is another important nutritional factor that is involved in the energy transfer of the algal cells as well as in the syntheses of phospholipids and nucleic acids. According to previous reports, the algal response to the $\mathrm{P}$ starvation is species-dependent [24, 25]. In this study, we found higher P concentrations promoted biomass accumulation within the tested P concentrations (Fig. 3F), yet the effect was less prominent compared with $\mathrm{N}$ concentrations (Fig. 3B), suggesting that $\mathrm{N}$ is more 
critical for algal growth than P. Similar to N, P concentrations just influenced the lipid content slightly (Fig. 3G). Therefore, the lipid productivity of Isochrysis was less affected by $\mathrm{P}$ than $\mathrm{N}$ and reached the highest value with 4.5-9.0 $\mathrm{mg} \mathrm{L}^{-1} \mathrm{P}$ (Fig. 3H).

\section{Growth and lipid production as affected by light intensities}

Aside from the cultivation medium composition, light intensity represents a critical environmental factor to influence the algal growth and lipid synthesis. Four light intensities including 30, 60, 120 and $240 \mu \mathrm{mol} \mathrm{m}^{-2} \mathrm{~s}^{-1}$ were tested (Fig. 4). When the light intensity increased from 30 to $60 \mu \mathrm{mol} \mathrm{m} \mathrm{s}^{-2}$, a typical light-dependent growth was observed in batch cultures of Isochrysis strains leading to the enhanced cell density (Fig. 4A). With a further increase in light intensity to $120 \mu \mathrm{mol} \mathrm{m} \mathrm{m}^{-2} \mathrm{~s}^{-1}$, no apparent impact on cell density (Fig. 4A) was observed, indicating the light saturation might be reached. A further increase to $240 \mu \mathrm{mol} \mathrm{m}^{-2} \mathrm{~s}^{-1}$ led to reduced amounts of algal cells, suggesting the photoinhibition has occurred which results in impaired algal growth and considerably attenuated cell density (Fig. 4A). Light intensity exhibited slight impact on lipid content (Fig. 4B), similar to N and P concentrations (Fig. 3C and 3G). Accordingly, the optimal lipid production of Isochrysis strains was achieved with light intensity of $60-120 \mu \mathrm{mol} \mathrm{m} \mathrm{m}^{-2} \mathrm{~s}^{-1}$ under the tested laboratory cultivation conditions (Fig. 4C).

\section{Lipid production in outdoor panel PBRs}

Since the outdoor culture conditions are much less controlled than the laboratory cultures, some algal strains with satisfactory indoor growth may not be suitable for outdoor cultivation. In this regard, the outdoor growth performance of the three 
Isochrysis strains were evaluated in panel PBRs, which offer a large surface area-to-volume ratio for efficient light utilization and biomass production [26]. As shown in Table 3, the biomass and lipid productivity of CS177 were significantly higher than other two, indicating its superior potential for the outdoor cultivation.

[Table 3 near here]

According to indoor results, CS177 suffered photoinhibition and growth deterioration when the light intensity reached $240 \mu \mathrm{mol} \mathrm{m} \mathrm{m}^{-2} \mathrm{~s}^{-1}$. This imposes a challenge for the outdoor growth of CS177 because the peak solar irradiation can reach as high as $2,500 \mu \mathrm{mol} \mathrm{m} \mathrm{m}^{-2} \mathrm{~s}^{-1}$ in summer, which may cause severe photosynthesis inhibition or even photooxidative damage to the algal cells. To avoid the ill-effect of strong solar irradiance and achieve a high efficiency of conversion of light energy, the adjustment of the optical path of PBRs is a feasible solution. As a key parameter of engineering design, the length of optical path has a remarkable effect on the production of cell mass as well as algae-derived metabolites [27-29]. In this study, three light paths of 1.8, 3.5, and $7.0 \mathrm{~cm}$ were examined in the panel PBRs with an initial inoculation cell density of $0.6 \mathrm{~g} \mathrm{~L}^{-1}$, corresponding to the areal cell densities of 10.8, 21.0 and $42.0 \mathrm{~g}$ $\mathrm{m}^{-2}$ (vertical surface), respectively. CS177 in the 1.8-cm PBR gave the lowest volumetric biomass productivity $\left(0.27 \mathrm{~g} \mathrm{~L}^{-1}\right.$ day $^{-1}$, Table 4 and Fig. 5A) and lowest areal biomass productivity $\left(5.2 \mathrm{~g} \mathrm{~m}^{-2}\right.$ day $\left.^{-1}\right)$. The poor productivities might arise from photoinhibition as the cultures were subjected to the highest per cell light intensity. In contrast, the highest volumetric biomass productivity $\left(0.57 \mathrm{~g} \mathrm{~L}^{-1}\right.$ day $\left.^{-1}\right)$ was achieved in the 3.5-cm panel PBR while the highest areal biomass productivity $\left(29.9 \mathrm{~g} \mathrm{~m}^{-2}\right.$ 
day $^{-1}$ ) was achieved in the 7.0-cm PBR (Table 4 and Fig. 5A). Similarly, the highest volumetric lipid productivity $\left(0.18 \mathrm{~g} \mathrm{~L}^{-1}\right.$ day $\left.^{-1}\right)$ was achieved in the 3.5-cm PBR, whereas the highest areal lipid productivity $\left(9.0 \mathrm{~g} \mathrm{~m}^{-2}\right.$ day $\left.^{-1}\right)$ was obtained in the 7.0-cm PBR (Table 4).

The highest areal biomass and lipid productivities obtained in the 7.0-cm PBR might be due to the longest PBR light path or the highest starting areal cell density. To confirm this, an identical areal cell density of $21.0 \mathrm{~g} \mathrm{~m}^{-2}$ was introduced to 1.8, 3.5, and 7.0-cm panel PBRs. As indicated by Table 4, the biomass and lipid productivities were positively dependent on the light path length of panel PBRs and reached the highest values (30.9 $\mathrm{g} \mathrm{m}^{-2}$ day $^{-1}$ and $8.9 \mathrm{~g} \mathrm{~m}^{-2}$ day $^{-1}$, respectively) in the 7.0-cm panel PBR. However, from a volumetric productivity standpoint, the biomass and lipid productivities were negatively affected by the length of panel PBRs and reached their maximum (0.88 and $0.28 \mathrm{~g} \mathrm{~L}^{-1}$ day $^{-1}$, respectively) in the $1.8 \mathrm{~cm}$-PBR (Table 4 and Fig. 5B).

[Table 4 near here]

\section{Enhanced lipid production by a two-stage semi-continuous culture strategy}

The biomass productivity may vary depending upon growth phases of the culture. As indicated by the batch culture in Fig. 5, the maximum biomass productivity occurred on days 2-4 regardless of the optical path length of PBRs and initial cell densities tested. In order to avoid the ill-effect of solar light and sustain maximum lipid production, a two-stage semi-continuous culture strategy was developed. A seed 
350

351

352

353

354

355

356

357

358

359

360

361

362

363

364

365

366

367

368

culture was firstly prepared in stage I. Since the cell density of initial inoculation should not be too high, cells were firstly inoculated at a low concentration of $0.3 \mathrm{~g} \mathrm{~L}^{-1}$ in a 7.0-cm panel PBR. A high cell density $\left(\sim 1.2 \mathrm{~g} \mathrm{~L}^{-1}\right)$ was reached after growing for 2 days, which served as the seed culture. In stage II, the seed culture was subsequently transferred to a 1.8-cm panel PBR in a semi-continuous mode for rapid biomass and lipid production. As shown in Fig. 6, the semi-continuous cultures sustained a stable production of biomass and lipid. The daily productivities of biomass and lipid were maintained at ca. 1.1 and $0.35 \mathrm{~g} \mathrm{~L}^{-1}$ day $^{-1}$, much higher than that in batch cultures.

Finally, the overall performance of Isochrysis CS177 was compared with some previously reported algae: not only from Isochrysis, but also from Chlorella, a genus known as a good candidate for oil production in biodiesel application. As shown in Table 5, the lipid-producing capacity of Isochrysis CS177 was comparable to or higher than many of these strains.

[Table 5 near here]

\section{Conclusions}

In this study, the biomass accumulation, lipid production and fatty acid profiles of fifteen Isochrysis strains were comprehensively evaluated. CS177 showed the best overall performance, from which the oil derived meets the specification established by U.S. and European standards. Considering its rapid growth, robustness in outdoor cultivation, lack of cell wall and the ability to accumulate value-added products, CS177 has the potential to be a promising candidate for oil production in biodiesel 
372 application .

374 Abbreviations:

375 AFDW: ash-free dry weight; DHA: docosahexaencic acid; EE: early exponential;

376 FAMEs: fatty acid methyl esters; LE: late exponential; LS: late stationary; N: nitrogen;

377 P: phosphorus; PBR: photobioreactor; TFA: total fatty acid.

380 Funding:

381 This work was financially supported by 'Young Eastern Scholar Program' at Shanghai

382 Institutions of Higher Learning (QD2015047), a start-up grant from the National 383 Youth Thousand Talents Program, National Natural Science Foundation of China 384 (31501493) and the Special Project of Marine Renewable Energy from the State

Oceanic Administration (SHME2011SW02).

\section{Consent for publication:}

388 All authors approved the manuscript.

\section{Conflict of Interest:}

391 The authors indicate no potential conflicts of interest. 


\section{References}

1. Hu, Q., Sommerfeld, M., Jarvis, E., Ghirardi, M., Posewitz, M., Seibert, M., \& Darzins, A. (2008). Microalgal triacylglycerols as feedstocks for biofuel production: perspectives and advances. Plant Journal, 54, 621-639.

2. Chisti, Y. (2007). Biodiesel from microalgae. Biotechnology Advances, 25, 294-306.

3. Liu, J., \& Hu, Q. (2013). Chlorella-Industrial production of biomass and chemicals. In: A. Richmond, Q Hu (Ed.), Handbook of microalgal cultures (2nd ed., pp. 327-338). New Jersey: Wiley Blackwell.

4. Li, Y., Horsman, M., Wu, N., Lan, C. Q., \& Dubois-Calero, N. (2008). Biofuels from microalgae. Biotechnology Progress, 24, 815-820.

5. Rodolfi, L., Zittelli, G. C., Bassi, N., Padovani, G., Biondi, N., Bonini, G., \& Tredici, M. R. (2009). Microalgae for oil: strain selection, induction of lipid synthesis and outdoor mass cultivation in a low-cost photobioreactor. Biotechnology and Bioengineering, 102, 100-112.

6. Liu, J., Sommerfeld, M., \& Hu, Q. (2013). Screening and characterization of Isochrysis strains and optimization of culture conditions for docosahexaenoic acid production. Applied Microbiology and Biotechnology, 97, 4785-4798.

7. Devos, M., Poisson, L., Ergan, F., \& Pencreac’h, G. (2006). Enzymatic hydrolysis of phospholipids from Isochrysis galbana for docosahexaenoic acid enrichment. Enzyme and Microbial Technology, 39, 548-554.

8. Sun, Z., Chen, Y., Mao, X., \& Liu, J. (2017). Physiological and biochemical 
changes reveal differential patterns of docosahexaenoic acid partitioning in two marine algal strains of Isochrysis. Marine Drugs, 15, 357.

9. Williams, P. J. B., \& Laurens, L. M. L. (2010). Microalgae as biodiesel \& biomass feedstocks: Review \& analysis of the biochemistry, energetics \& economics.

10. Christie, W. W. (2003). Lipid analysis: isolation, separation, identification and 
439

17. Lacour, T., Sciandra, A., Talec, A., Mayzaud, P., \& Bernard, O. (2012). Neutral lipid and carbohydrate productivities as a response to nitrogen starus in Isochrysis sp. (T-ISO; Haptophyceae): starvation versus limitation. Journal of Phycology, 48, 647-656.

18. Converti, A., Casazza, A. A., Ortiz, E. Y., Perego, P., \& Borghi, M. D. (2009). Effect of temperature and nitrogen concentration on the growth and lipid content of Nannochloropsis oculata and Chlorella vulgaris for biodiesel production. Chemical Engineering and Processing, 48, 1146-1151.

19. Sun, Z., Zhou, Z., Gerken, H., Chen, F., \& Liu, J. (2015). Screening and characterization of oleaginous Chlorella strains and exploration of Chlorella protothecoides for oil production. Bioresource Technology, 184, 53-62.

20. Liu, J., Sun, Z., \& Chen, F. (2013). Heterotrophic production of microalgal oils. In: A. Pandey, D. J. Lee, Y. Chisti, C. R. Soccol (Ed.), Biofuels from algae (pp. 111-142). Amsterdam: Elsevier.

21. Gladue, R., \& Maxey, J. (1994). Microalgal feeds for aquaculture. Journal of Applied Phycology, 6, 131-141.

22. Guerrini, F., Cangini, M., Boni, L., Trost, P., \& Pistocchi, R. (2000). Metabolic responses of the diatom Achnanthes brevipes (Bacillariophyceae) to nutrient limitation. Journal of Phycology, 36, 882-890.

23. Wen, Z. Y., \& Chen, F. (2000). Heterotrophic production of eicosapentaenoid acid by the diatom Nitzschia laevis: effects of silicate and glucose. Journal of Industrial 
461

24. Khozin-Goldberg, I., \& Cohen, Z. (2006). The effect of phosphate starvation on the lipid and fatty acid composition of the fresh water eustigmatophyte Monodus subterraneus. Phytochemistry, 67, 696-701.

25. Yongmanitchai, W., \& Ward, O. P. (1991). Growth of and omega-3 fatty acid production by Phaeodactylum tricornutum under different culture conditions. Applied and Environmental Microbiology, 57, 419-425.

26. Ugwu, C. U., Aoyagi, H., \& Uchiyama, H. (2008). Photobioreactors for mass cultivation of algae. Bioresource Technology, 99, 4021-4028.

27. Hu, Q., \& Richmond, A. (1994). Optimizing the population density in Isochrysis galbana grown outdoors in a glass column photobioreactor. Journal of Applied Phycology, 6, 391-396.

28. Hu, Q., Guterman, H., \& Richmond, A. (1996). A flat inclined modular photobioreactor for outdoor mass cultivation of photoautotrophs. Biotechnology and Bioengineering, 51, 51-60.

29. Richmond, A. (2003). Biological principles of mass cultivation. In A. Richmond (Ed.), Handbook of microalgal culture: biotechnology and applied phycology (pp. 125-177). New Jersey: Wiley-Blackwell.

30. Molina Grima, E., Sánchez Pérez, J. A., García Sánchez, J. L., García Camacho, F., \& López Alonso, D. (1992). EPA from Isochrysis galbana. Growth conditions and productivity. Process Biochemistry, 27, 299-305.

31. Molina Grima, E., Sánchez Pérez, J. A., García Camacho, F., García Sánchez, J. 
L., Acién Fernández, F. G., \& López Alonso, D. (1994). Outdoor culture of Isochrysis galbana ALII-4 in a closed tubular photobioreactor. Journal of Biotechnology, 37, 159-166.

32. Huerlimann, R., De Nys, R., \& Heimann, K. (2010). Growth, lipid content, productivity and fatty acid composition of tropical microalgae for scale-up production. Biotechnology and Bioengineering, 107, 245-257.

33. Feng, D., Chen, Z., Xue, S., \& Zhang, W. (2011). Increased lipid production of the marine oleaginous microalgae Isochrysis zhangjiangensis (Chrysophyta) by nitrogen supplement. Bioresource Technology, 102, 6710-6716.

34. Moheimani, N. (2013). Long-term outdoor growth and lipid productivity of Tetraselmis suecica, Dunaliella tertiolecta and Chlorella sp. (Chlorophyta) in bag photobioreactors. Journal of Applied Phycology, 25, 167-176.

35. Zhou, X., Xia, L., Ge, H., Zhang, D., \& Hu, C. (2013). Feasibility of biodiesel production by microalgae Chlorella sp. (FACHB-1748) under outdoor conditions. Bioresource Technology, 138, 131-135.

36. Guccione, A., Biondi, N., Sampietro, G., Rodolfi, L., Bassi, N., \& Tredici, M. (2014). Chlorella for protein and biofuels: from strain selection to outdoor cultivation in a green wall panel photobioreactor. Biotechnology for Biofuels, 7, 84.

37. Breuer, G., Lamers, P. P., Martens, D. E., Draaisma, R. B., \& Wijffels, R. H. (2012). The impact of nitrogen starvation on the dynamics of triacylglycerol accumulation in nine microalgae strains. Bioresource Technology, 124, 217-226.

38. Munkel, R., Schmid-Staiger, U., Werner, A., \& Hirth, T. (2013). Optimization of 
504 outdoor cultivation in flat panel airlift reactors for lipid production by Chlorella 505 vulgaris. Biotechnology and Bioengineering, 110, 2882-2893.

506

507

508

509

510

511

512

513

514

515

516

517

518

519

520

521

522

523

524

525

526 
528 Fig. 1. The cell density (A), lipid content (B), and lipid productivity (C) of fifteen

529 Isochrysis strains. Data were obtained from cells grown for 10 days with continuous 530 illumination of $60 \mu \mathrm{M} \mathrm{s}^{-1} \mathrm{~m}^{-2}$.

531

532

533

534

535

536

537

538

539

540

541

542

543

544

545

546

547

548

549

550

551

552

553

554

Fig. 2. Lipid content (A) and fatty acid profile of CCMP1244 (B), CCMP1324 (C) and CS177 (D) as affected by growth phase - early exponential (EE, white column), late exponential (LE, grey column) and late stationary (LS, black column).

Fig. 3. Growth and lipid production as affected by various starting concentrations of N (A-D) or P (E-H). The initial N concentrations used were 25, 50, 100 and $200 \mathrm{mg}$ $\mathrm{L}^{-1}$; the initial $\mathrm{P}$ concentrations were $1.1,2.3,4.5$ and $9.0 \mathrm{mg} \mathrm{L}^{-1}$.

Fig. 4. The cell density (A), lipid content (B) and lipid productivity (C) as affected by various light intensities of 30,60, 120 and $240 \mu \mathrm{M} \mathrm{s}^{-1} \mathrm{~m}^{-2}$.

Fig. 5. Biomass yield of CS177 in outdoor panel PBRs as affected by various optical paths of $1.8 \mathrm{~cm}$ (square), $3.8 \mathrm{~cm}$ (circle) and $7.0 \mathrm{~cm}$ (triangle). (A): the initial volumetric cell density was fixed at $0.6 \mathrm{~g} \mathrm{~L}^{-1}$, (B): the initial areal cell density was fixed at $21 \mathrm{~g} \mathrm{~m}^{-2}$.

Fig. 6. A two-stage culture strategy for enhanced and stable lipid production. (A): cell density, (B) lipid content, (C): biomass /lipid productivity. Cells were first inoculated in a 7.0-cm panel PBR with a low cell density of $0.3 \mathrm{~g} \mathrm{~L}^{-1}$ and allowed to grow for 2 days to reach a high cell density of about $1.2 \mathrm{~g} \mathrm{~L}^{-1}$, which were then transferred to a 1.8-cm panel PBR for rapid biomass and lipid production. Semi-continuous cultivation was deployed in the thin PBR, with a harvest of $3 / 4$ cultures per 3 days. 
Table 1 Fatty acid profiles of the fifteen Isochrysis strains cultured for 10 days. Data were expressed as percentage of total fatty acids (\%).

\begin{tabular}{|c|c|c|c|c|c|c|c|c|c|c|}
\hline Strain & C14:0 & C16:0 & C16:1 & C18:0 & C18:1 & C18:2 & C18:3 & C18:4 & $\mathrm{C} 22: 0$ & $\mathrm{C} 22: 6$ \\
\hline ССMP 355 & $30.8 \pm 1.6$ & $17.9 \pm 1.0$ & $1.2 \pm 0.1$ & $1.1 \pm 0.1$ & $28.1 \pm 1.6$ & $2.7 \pm 0.2$ & $1.6 \pm 0.1$ & $3.2 \pm 0.1$ & - & $8.3 \pm 0.5$ \\
\hline CCMP 463 & $9.3 \pm 0.5$ & $20.3 \pm 0.7$ & $1.5 \pm 0.1$ & $2.9 \pm 0.2$ & $32.1 \pm 1.8$ & $4.0 \pm 0.2$ & $3.7 \pm 0.2$ & $12.1 \pm 0.5$ & $1.5 \pm 0.1$ & $10.6 \pm 0.4$ \\
\hline CCMP 1244 & $11.4 \pm 0.4$ & $16.3 \pm 0.9$ & $2.8 \pm 0.2$ & $1.4 \pm 0.1$ & $21.5 \pm 1.1$ & $2.2 \pm 0.1$ & $4.1 \pm 0.2$ & $19.8 \pm 1.1$ & $0.9 \pm 0.1$ & $15.5 \pm 0.8$ \\
\hline ССMP 1324 & $10.3 \pm 0.5$ & $16.8 \pm 0.8$ & $1.4 \pm 0.1$ & $1.8 \pm 0.1$ & $29.2 \pm 1.0$ & $4.7 \pm 0.3$ & $4.2 \pm 0.2$ & $15.5 \pm 0.8$ & $1.0 \pm 0.0$ & $12.2 \pm 0.7$ \\
\hline ССMP 1611 & $25.8 \pm 1.3$ & $15.4 \pm 0.6$ & $0.9 \pm 0.0$ & $2.2 \pm 0.1$ & $34.0 \pm 2.0$ & $5.7 \pm 0.3$ & $1.7 \pm 0.1$ & $4.4 \pm 0.2$ & - & $6.1 \pm 0.2$ \\
\hline UTEX 1292 & $16.6 \pm 0.9$ & $14.4 \pm 0.8$ & $1.1 \pm 0.1$ & $1.4 \pm 0.1$ & $31.4 \pm 1.6$ & $7.1 \pm 0.4$ & $3.4 \pm 0.2$ & $5.9 \pm 0.3$ & - & $11.3 \pm 0.6$ \\
\hline UTEX 2307 & $26.4 \pm 0.8$ & $15.0 \pm 0.7$ & $1.3 \pm 0.0$ & $0.8 \pm 0.0$ & $30.0 \pm 1.2$ & $5.0 \pm 0.2$ & $2.3 \pm 0.1$ & $8.7 \pm 0.4$ & & $9.4 \pm 0.4$ \\
\hline CS177 & $25.0 \pm 1.1$ & $16.1 \pm 0.9$ & $1.6 \pm 0.1$ & $0.5 \pm 0.0$ & $27.3 \pm 1.7$ & $9.8 \pm 0.6$ & $3.3 \pm 0.2$ & $9.6 \pm 0.3$ & $0.2 \pm 0.0$ & $5.3 \pm 0.3$ \\
\hline CS254 & $23.5 \pm 1.0$ & $15.8 \pm 0.6$ & $0.8 \pm 0.0$ & $1.4 \pm 0.1$ & $31.3 \pm 1.5$ & $5.0 \pm 0.3$ & $4.4 \pm 0.2$ & $4.3 \pm 0.1$ & - & $8.3 \pm 0.3$ \\
\hline CСАР 927/1 & $21.9 \pm 0.9$ & $15.9 \pm 0.8$ & $0.7 \pm 0.1$ & $1.0 \pm 0.0$ & $29.5 \pm 1.6$ & $5.4 \pm 0.2$ & $4.0 \pm 0.2$ & $4.6 \pm 0.2$ & - & $11.1 \pm 0.6$ \\
\hline
\end{tabular}

-, below detection level 
Table 2 The predicted properties of biodiesel from Isochrysis strains

\begin{tabular}{|c|c|c|c|c|c|c|}
\hline & $\begin{array}{c}\text { Kinematic viscosity } \\
40^{\circ} \mathrm{C}\left(\mathrm{mm}^{2} \mathrm{~s}^{-1}\right)\end{array}$ & $\begin{array}{c}\text { Specific gravity } \\
\left(\mathrm{kg} \mathrm{L}^{-1}\right)\end{array}$ & Cloud point $\left({ }^{\circ} \mathrm{C}\right)$ & Cetane number & $\begin{array}{l}\text { Iodine value } \\
\text { (g I } 2 / 100 \mathrm{~g} \text { ) }\end{array}$ & $\begin{array}{l}\text { Higher heating value } \\
(\mathrm{MJ} / \mathrm{kg})\end{array}$ \\
\hline CCMP 355 & 4.56 & 0.88 & 6.33 & 56.06 & 88.78 & 40.33 \\
\hline CCMP 463 & 4.17 & 0.88 & -1.97 & 51.91 & 135.02 & 41.43 \\
\hline CСMP 715 & 4.38 & 0.88 & 2.61 & 54.20 & 109.53 & 40.83 \\
\hline ССMP 1244 & 3.86 & 0.88 & -8.49 & 48.65 & 171.32 & 42.29 \\
\hline ССMР 1324 & 4.02 & 0.88 & -5.11 & 50.34 & 152.50 & 41.84 \\
\hline CСMP 1611 & 4.54 & 0.88 & 5.91 & 55.84 & 91.13 & 40.39 \\
\hline UTEX 987 & 4.34 & 0.88 & 1.57 & 53.68 & 115.29 & 40.96 \\
\hline UTEX 1292 & 4.27 & 0.88 & 0.17 & 52.98 & 123.09 & 41.15 \\
\hline UTEX 2307 & 4.33 & 0.88 & 1.39 & 53.59 & 116.32 & 40.99 \\
\hline CS 177 & 4.39 & 0.88 & 2.82 & 54.30 & 108.32 & 40.80 \\
\hline CS 254 & 4.43 & 0.88 & 3.65 & 54.72 & 103.71 & 40.69 \\
\hline CCAP 927/1 & 4.33 & 0.88 & 1.53 & 53.66 & 115.51 & 40.97 \\
\hline CCAP 927/12 & 4.40 & 0.88 & 3.03 & 54.41 & 107.15 & 40.77 \\
\hline CCAP 927/14 & 3.86 & 0.88 & -8.42 & 48.69 & 170.94 & 42.28 \\
\hline LABI 1100 & 4.43 & 0.88 & 3.61 & 54.70 & 103.94 & 40.69 \\
\hline Biodiesel & $4-5$ & $0.87-0.89$ & & $44-55$ & & $38-41$ \\
\hline ASTM D6751 & $1.9-6.0$ & $0.85-0.90$ & & Min 47 & & \\
\hline EN 14214 & $3.5-5.0$ & & & Min 51 & Max 120 & \\
\hline
\end{tabular}


Table 3 Biomass and lipid productivities of three Isochrysis strains grown in an outdoor panel PBR.

\begin{tabular}{lccc}
\hline & $\begin{array}{c}\text { Cell density } \\
\left(\mathrm{g} \mathrm{L}^{-1}\right)\end{array}$ & $\begin{array}{c}\text { Biomass productivity } \\
\left(\mathrm{g} \mathrm{L}^{-1} \text { day }^{-1}\right)\end{array}$ & $\begin{array}{c}\text { Lipid productivity } \\
\left(\mathrm{mg} \mathrm{L}^{-1} \text { day }^{-1}\right)\end{array}$ \\
\hline CCMP 1244 & $3.8 \pm 0.2^{\mathrm{ab}}$ & $0.53 \pm 0.03^{\mathrm{ab}}$ & $135 \pm 9^{\mathrm{a}}$ \\
CCMP 1324 & $3.5 \pm 0.2^{\mathrm{a}}$ & $0.48 \pm 0.03^{\mathrm{ac}}$ & $140 \pm 10^{\mathrm{a}}$ \\
CS 177 & $4.2 \pm 0.3^{\mathrm{b}}$ & $0.60 \pm 0.03^{\mathrm{b}}$ & $180 \pm 11^{\mathrm{b}}$ \\
\hline
\end{tabular}

Cells were harvested after 6-day cultivation for analysis. Values in each column followed by the same letter are not significantly different $(\mathrm{P}>0.05)$. 
Table 4 Biomass and lipid productivities of CS177 grown in an outdoor panel PBR.

\begin{tabular}{|c|c|c|c|c|c|c|c|c|}
\hline \multirow[b]{2}{*}{ Light path $(\mathrm{cm})$} & \multicolumn{2}{|c|}{$\begin{array}{l}\text { Volumetric cell density } \\
\qquad\left(\mathrm{g} \mathrm{L}^{-1}\right)\end{array}$} & \multicolumn{2}{|c|}{$\begin{array}{l}\text { Areal cell density } \\
\qquad\left(\mathrm{g} \mathrm{m}^{-2}\right)\end{array}$} & \multicolumn{2}{|c|}{$\begin{array}{l}\text { Volumetric productivity } \\
\qquad\left(\mathrm{g} \mathrm{L}^{-1} \text { day }^{-1}\right)\end{array}$} & \multicolumn{2}{|c|}{$\begin{array}{l}\text { Areal productivity } \\
\qquad\left(\mathrm{g} \mathrm{m}^{-2} \text { day }^{-1}\right)\end{array}$} \\
\hline & Initial & Final & Initial & Final & Biomass & Lipid & Biomass & Lipid \\
\hline \multicolumn{9}{|c|}{ Initial volumetric cell density $=0.6 \mathrm{~g} \mathrm{~L}^{-1}$} \\
\hline 1.8 & 0.6 & $2.2 \pm 0.1^{\mathrm{a}}$ & 10.8 & $42.4 \pm 1.9^{\mathrm{a}}$ & $0.27 \pm 0.02^{\mathrm{a}}$ & $0.08 \pm 0.00^{\mathrm{a}}$ & $5.2 \pm 0.3^{\mathrm{a}}$ & $1.5 \pm 0.1^{\mathrm{a}}$ \\
\hline 3.5 & 0.6 & $4.0 \pm 0.2^{b}$ & 21.0 & $152.4 \pm 7.7^{\mathrm{b}}$ & $0.57 \pm 0.04^{b}$ & $0.18 \pm 0.01^{\mathrm{b}}$ & $21.6 \pm 1.4^{\mathrm{b}}$ & $6.7 \pm 0.3^{b}$ \\
\hline 7.0 & 0.6 & $3.0 \pm 0.2^{c}$ & 42.0 & $225.0 \pm 14.3^{c}$ & $0.39 \pm 0.02^{c}$ & $0.12 \pm 0.01^{\mathrm{c}}$ & $29.9 \pm 1.6^{c}$ & $9.0 \pm 0.6^{\mathrm{c}}$ \\
\hline \multicolumn{9}{|c|}{ Initial areal cell density $=21.0 \mathrm{~g} \mathrm{~m}^{-2}$} \\
\hline 1.8 & 1.2 & $6.5 \pm 0.3^{\mathrm{a}}$ & $\sim 21.0$ & $123.1 \pm 6.3^{\mathrm{a}}$ & $0.88 \pm 0.05^{a}$ & $0.28 \pm 0.02^{\mathrm{a}}$ & $16.7 \pm 1.1^{\mathrm{a}}$ & $5.3 \pm 0.3^{\mathrm{a}}$ \\
\hline 3.5 & 0.6 & $4.3 \pm 0.2^{b}$ & 21.0 & $163.0 \pm 8.1^{b}$ & $0.62 \pm 0.03^{\mathrm{b}}$ & $0.19 \pm 0.01^{\mathrm{b}}$ & $24.0 \pm 1.4^{\mathrm{b}}$ & $7.2 \pm 0.4^{\mathrm{b}}$ \\
\hline 7.0 & 0.3 & $2.7 \pm 0.1^{\mathrm{c}}$ & 21.0 & $208.2 \pm 9.2^{\mathrm{c}}$ & $0.41 \pm 0.03^{\mathrm{c}}$ & $0.12 \pm 0.01^{\mathrm{c}}$ & $30.9 \pm 2.2^{c}$ & $8.9 \pm 0.6^{\mathrm{c}}$ \\
\hline
\end{tabular}

1 'Area' refers to the vertical surface of the PBR.

Cells were harvested after 6-day cultivation for analysis. Values in each column within the same experiment followed by the same letter are not significantly different $(\mathrm{P}>0.05)$. 
Table 5 Photoautotrophic lipid production of Isochrysis CS177 in comparison with previously reported microalgae

\begin{tabular}{|c|c|c|c|c|c|}
\hline Algal strain & Culture conditions & $\begin{array}{c}\text { Biomass productivity } \\
\quad\left(\mathrm{g} \mathrm{L} \mathrm{L}^{-1} \text { day }^{-1}\right)\end{array}$ & $\begin{array}{c}\text { Lipid content } \\
\text { (\% DW) }\end{array}$ & $\begin{array}{l}\text { Lipid productivity } \\
\left(\mathrm{mg} \mathrm{L}^{-1} \text { day }^{-1}\right)\end{array}$ & References \\
\hline Isochrysis sp. & O, 10-L panel PBR (batch) & 0.88 & 31.9 & 281 & This study \\
\hline \multirow[t]{2}{*}{ Isochrysis galbana } & I, 1-L flasks & 0.31 & 22.0 & 68 & [30] \\
\hline & O, 50-L tubular PBR & 0.32 & & & [31] \\
\hline Isochrysis sp. & I, 15-L Carboy & 0.09 & 23.5 & 21 & [32] \\
\hline Isochrysis zhangjiangensis & I, 600-mL column & 0.34 & 40.9 & 141 & [33] \\
\hline Isochrysis sp. & I, 0.5-5-L flask & 0.15 & 51.5 & 78 & [6] \\
\hline \multirow[t]{2}{*}{ Chlorella protothecoides } & I, 100-mL column & 0.57 & 48.3 & 280 & [19] \\
\hline & O, 50-L panel PBR & 0.87 & 48.9 & 340 & \\
\hline Chlorella sp. & O, 10-L panel PBRs & 0.6 & 26.6 & 160 & \\
\hline Chlorella vulgaris & I, 250-mL flasks & 0.49 & 35.4 & 170 & [37] \\
\hline Chlorella vulgaris & O, 30-L panel PBRs & 0.67 & 44.6 & 390 & [38] \\
\hline Chlorella zofingiensis & I, 250-mL flasks & 0.67 & 44.8 & 301 & [37] \\
\hline
\end{tabular}

I: Indoor; O: Outdoor 


\section{University Library}

\section{- M M N E R VA A gateway to Melbourne's research publications}

Minerva Access is the Institutional Repository of The University of Melbourne

Author/s:

Sun, Z;Wei, H;Zhou, Z-G;Ashokkumar, M;Liu, J

Title:

Screening of Isochrysis Strains and Utilization of a Two-Stage Outdoor Cultivation Strategy for Algal Biomass and Lipid Production

Date:

2018-08-01

Citation:

Sun, Z., Wei, H., Zhou, Z. -G., Ashokkumar, M. \& Liu, J. (2018). Screening of Isochrysis Strains and Utilization of a Two-Stage Outdoor Cultivation Strategy for Algal Biomass and Lipid Production. APPLIED BIOCHEMISTRY AND BIOTECHNOLOGY, 185 (4), pp.1100-1117. https://doi.org/10.1007/s12010-018-2717-3.

Persistent Link:

http://hdl.handle.net/11343/241898 